\title{
PINDORAMA ANTES DO BRASIL
}

PINDORAMA BEFORE BRAZIL

PINDORAMA ANTES DE BRAZIL

Hilton P. Silva $ه$

Universidade Federal do Pará I Belém - PA - Brasil 


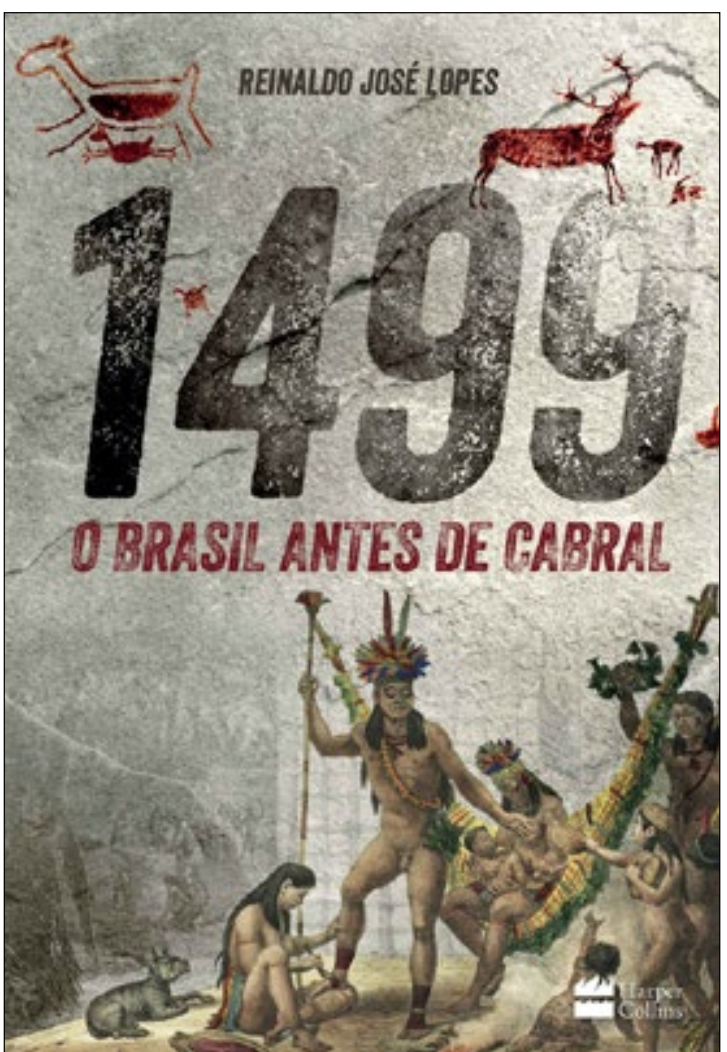

Lopes, R. J. 2017. 1499: o Brasil antes de Cabral. Rio de Janeiro: Harper Collins

Sempre houve grande curiosidade sobre como era a vida dos grupos nativos do Brasil antes da chegada dos europeus. As especulações iam desde um paraíso terrestre, como consta na carta de Pero Vaz de Caminha, que alguns consideram a "certidão de nascimento" do país, até uma terra de canibais selvagens, com toques de inocência, como ocorre nas crônicas de Hans Staden. O excelente livro do jornalista Reinaldo José Lopes, que há muito se especializou em cobrir assuntos científicos, apresenta ampla cobertura sobre a vida dos grupos humanos no período pré-colonial, desde descobertas mais antigas acerca do processo de ocupação do continente americano até pesquisas realizadas no alto Xingu e na ilha do Marajó.

A introdução, cujo título é "O passado não é mais como era antigamente", apresenta a proposta e o roteiro do livro (que não tem sumário). Segundo o autor: "Este livro é uma modesta tentativa de tirar da sua cabeça a imagem, a um só tempo clássica e profundamente equivocada, do Brasil pré-Cabral como um paraíso terrestre tropical, no qual a mão do homem (e a da mulher, lógico) pouco havia mexido" (Lopes 2017:12). A obra se propõe a mostrar um "retrato renovado do Brasil pré-cabralino como um mosaico de civilizações complexas e populosas" (Lopes 2017:13), seguindo, em sequência cronológica, pela apresentação das descobertas sobre os grupos mais antigos, como o que originou "Luzia", o material humano mais antigo do continente, passando pelos grandes aglomerados populacionais do Xingu, as terras pretas do Marajó, a diversidade cultural e linguística dos povos do passado, chegando até discussões mais recentes sobre o DNA dos nativos contemporâneos e a origem das florestas antropogênicas. $\mathrm{O}$ autor termina a introdução com o subtítulo "Motivos para se importar", ponto do texto onde chama a atenção para dois aspectos sobre a relevância de conhecer a história dessas terras antes da constituição da nação brasileira: 1) o fato ainda 
pouco (re)conhecido, ou admitido, de que grande parte da população brasileira atual - variando de uma frequência superior a $90 \%$ em algumas cidades do Amazonas até cerca de $10 \%$ ou menos em áreas do Rio Grande do Sul - tem ancestrais maternos (a maioria) ou paternos ameríndios; e 2) as potenciais lições que podem ser tiradas das descobertas sobre os modos de vida e de interação com os recursos naturais dos povos do passado, muitos dos quais utilizavam e manejavam intensamente os recursos, aparentemente contribuindo para ampliar sua diversidade, ao invés de diminuí-la, como vem ocorrendo atualmente, com efeitos climáticos e sociais catastróficos. Certamente, ambos são motivos relevantes, que se somam à necessidade crescente de ter materiais acessíveis a um amplo público, acadêmico ou não, sobre pesquisas científicas realizadas no Brasil, por pesquisadores brasileiros, sobre o nosso passado.

O capítulo 1, intitulado "Quem é você, Luzia?", aborda as discussões realizadas nas últimas décadas sobre o povoamento do continente americano. $\mathrm{O}$ autor inicia fazendo um apanhado sobre os achados na região de Lagoa Santa, em Minas Gerais, entre os quais se incluem a famosa "Luzia". As pesquisas na região foram iniciadas ainda no século XIX pelo explorador/naturalista dinamarquês Peter Lund (1801-1880) e continuam até os dias atuais. Os materiais que ficaram conhecidos na imprensa como pertencentes à Luzia incluem um crânio e alguns fragmentos de ossos longos ${ }^{1}$, datados de cerca de 11.500 anos, escavados em 1975 pela equipe da arqueóloga francesa Annette Laming-Emperaire (1917-1977), guardados no Museu Nacional da Universidade Federal do Rio de Janeiro (MN/UFRJ), e analisados na década de 1990 pelo bioarqueólogo Walter Neves, que lhe deu este nome em dupla homenagem: à Lucy, o fóssil de Australopithecus afarensis descoberto por Donald Johanson e Tom Gray, na Etiópia, em 1974, considerado um dos mais importantes potenciais ancestrais dos humanos atuais, e em homenagem à sua mãe, que se chamava Luzia Neves. O capítulo prossegue apresentando brevemente o que se conhece sobre a ecologia do Brasil central e o modo de vida das pessoas contemporâneas à Luzia, abordando as discussões sobre os estudos genéticos realizados em populações pré-históricas e atuais para tentar compreender a antiguidade e as rotas dos primeiros imigrantes para o continente americano, e as controvérsias entre os resultados dos estudos genéticos e bioarqueológicos. Este capítulo, em

1 Quase a totalidade do material referente à Luzia foi perdida, juntamente com centenas de esqueletos e objetos, préhistóricos e históricos, depositados nas coleções do Setor de Antropologia Biológica do Museu Nacional, no incêndio ocorrido em 2 de setembro de 2018, caracterizando a maior perda científica da história do Brasil e uma das maiores do mundo no campo da bioantropologia. Dedico esta resenha ao Museu Nacional. 
que pese apresentar um bom panorama geral, se beneficiaria de uma discussão mais sólida sobre as contribuições que os estudos brasileiros utilizando métodos craniométricos e genéticos têm dado para a compreensão do povoamento das Américas e que têm sido, em grande parte, ignorados pela literatura norte americana (Silva \& Rodrigues-Carvalho 2006; Neves \& Piló 2008). Para exemplificar as dificuldades interpretativas das diversas evidências, o capítulo encerra com uma especulação sobre estudos genéticos realizados com material do Museu Nacional (Gonçalves et al. 2013; Malaspinas et al. 2014), já demonstrada incorreta, a de que "não se pode descartar a possibilidade de um erro de classificação do museu onde os ossos (dos quais foi extraído DNA) de crânios polinésios [foram] etiquetados como de Botocudos" (Lopes 2017:61). Estudos craniométricos já demonstraram que todos os materiais analisados na amostra que originou o DNA discutido nos artigos têm as mesmas características físicas dos grupos Botocudos, morfologicamente distintos de outras populações ameríndias (Strauss et al. 2015).

O capítulo 2 é chamado de "As conchas e os mortos" e apresenta os debates sobre a presença e o significado dos grupos de sambaquis, aglomerados de conchas de moluscos que serviram de locais de enterramento e convivência de grupos pescadorescaçadores-coletores e ocorrem em regiões costeiras desde o Norte até o Sul do país, construídos a partir de 10 mil até cerca de 2.500 anos atrás. Este capítulo também faz uma boa apresentação geral sobre o processo pré-contato de ocupação do litoral brasileiro, sobre ecologia humana e sobre as diferenças entre sambaquis oceânicos e de rios, mas a discussão é superficial, focando-se em poucos exemplos e ignorando partes importantes da literatura sobre o tema.

O capítulo 3, "Revolução agrícola made in Brazil', apresenta o processo de desenvolvimento de plantas de uso doméstico, como a castanhado-pará, a pupunha, o cacau e a mandioca, e da chamada Terra Preta de Índio, existente em amplas áreas da Amazônia que, por sua fertilidade, possibilitou o aparecimento de densos aglomerados populacionais e a criação de grandes áreas de florestas antropogênicas. Este capítulo demonstra claramente a necessidade de trabalhos interdisciplinares, entre arqueólogos, bioantropólogos, geólogos, botânicos e outros, para a compreensão de processos complexos como o são a domesticação e a ocupação de vastas regiões do continente americano.

"Os filhos da serpente" é o título escolhido para o capítulo 4 , e se justifica pela frequente manifestação deste animal nas belas cerâmicas amazônicas. Para Lopes (2017:109), “A partir dos primeiros séculos do que costumamos chamar 
de Era Cristã, ocorre um aumento inegável da densidade populacional e da complexidade social, política e cultural dos povos que habitavam o que um dia seria o território brasileiro.... Ele escolhe como área-foco para fazer essa discussão a ilha do Marajó, utilizando, sobretudo, os trabalhos realizados na última década pela arqueóloga Denise Pahl Schaan (1962-2018), que fez contribuições notáveis à arqueologia brasileira e mundial ao pesquisar a construção dos tesos e a complexidade dos processos adaptativos ecológicos dos povos pré-coloniais do arquipélago marajoara. Este é um capítulo curto e bastante focado, quase uma homenagem aos trabalhos da professora Denise, que foi uma das fundadoras do Programa de PósGraduação em Antropologia da Universidade Federal do Pará (UFPA) e faleceu no auge de sua produtividade acadêmica. Ao longo do livro, a importância das pesquisas de Schaan é notável, pois diversos capítulos citam grande parte dos seus trabalhos e perspectivas, sendo quase uma coletânea sobre a produção desta importante pesquisadora, que nos deixou precocemente no início de 2018.

O capítulo 5 recebe o título de "No reino das Amazonas" e discorre sobre o período imediatamente anterior à chegada dos europeus até os primeiros contatos, que registraram grandes aglomerados populacionais ao longo do rio Amazonas. Nele, o autor discute os achados no Pará, nas regiões de Santarém e Monte Alegre, no Amapá e no Acre, que vão desde pinturas em cavernas, cerâmicas altamente elaboradas e decoradas, megalitos até os geoglifos, que só podem ser vistos do céu. Em conjunto, as pesquisas demonstram a crescente presença e ação humana sobre os ecossistemas na região desde aproximadamente $10 \mathrm{mil}$ anos antes de Cristo até a chegada dos europeus. Este é o capítulo mais longo e detalhado do livro, e demonstra a grande quantidade e complexidade das pesquisas realizadas na Amazônia nas últimas décadas, mas, sabiamente, reitera que, embora muito já tenha sido descoberto, muito mais ainda há a ser investigado.

O penúltimo capítulo, "Tupi or not Tupi", concentra-se na diversidade linguística dos povos do passado e do presente para fazer inferências sobre os processos de dispersão dos diversos grupos pelo território brasileiro précabralino. Além da linguística e da arqueologia, o autor também se baseia em diversos estudos etnográficos que, através de mitos e ritos, recontam as migrações e viagens comerciais dos ancestrais de diversos grupos da bacia amazônica, demonstrando extensas redes de trocas desde o oeste até o leste da região. Parte considerável do capítulo também é dedicada às relações entre os 
grupos Aruak e Tupi, que originaram a maioria das populações encontradas pelos europeus.

"Por que o Brasil pré-histórico foi derrotado?" é o título do epílogo, que discute os efeitos do contato com os europeus e seus desdobramentos. Este capítulo lembra muito o livro "Armas, germes e aço - os destinos das sociedades humanas" (Diamond 2001), uma vez que considera os mesmos argumentos em relação aos diferentes processos de domesticação, às diferentes doenças e às diferentes maneiras de controle social (Estado) para explicar as assimetrias entre os colonizadores e os nativos, e o rápido declínio populacional pós-colonial dos ameríndios. O capítulo também chama a atenção para a contínua resistência dos povos originários ao domínio colonial, evidenciando que o passado profundo do Brasil é tão rico quanto o do Velho Mundo, sendo igualmente importante conhecê-lo e valorizá-lo.

"O Brasil antes de Cabral" utiliza fontes bibliográficas sólidas e traz inserções interessantes no capítulo chamado "Explicação técnica", que explicita termos potencialmente menos conhecidos do público não acadêmico, como DNA, métodos de datação, sistemas de organização social, diversidade linguística etc., o que é uma novidade interessante e útil em textos de divulgação científica. No entanto, não tem gráficos, tabelas ou ilustrações, o que é incomum neste tipo de literatura. O autor usa o termo pré-história para se referir ao período anterior à chegada dos europeus, indicando que, para ele, a história só começa com a escrita trazida pelos colonizadores. Esta é uma visão que, atualmente, encontra resistência entre os historiadores, que não consideram mais adequado o uso do termo, entendendo que mesmo os povos ágrafos também têm História.

Como os livros escolares nacionais abordam o tema do povoamento das Américas e do Brasil pré-colonial de maneira bastante superficial, em geral, apenas apresentando o exemplo de Luzia, e depois "pulam" para os grupos indígenas atuais, como se estes fossem relíquias do passado, este livro também pode ser usado tanto no ensino médio como no superior, para mitigar a carência de material escolar sobre o tema.

O livro apresenta, em uma linguagem jornalística e fluida, de fácil compreensão, um excelente panorama sobre a vida dos grupos nativos do território que, hoje, chamamos de Brasil, utilizando os mais recentes desenvolvimentos de pesquisas antropológicas multidisciplinares. É uma importante contribuição para a divulgação científica de temas relacionados à arqueologia, à bioantropologia, à bioarqueologia, à etnologia e à história do Brasil, e uma agradável leitura para curiosos, estudantes e especialistas. 


\section{REFERÊNCIAS}

Diamond, J. 2001. Armas, germes e aço - os destinos das sociedades humanas. São Paulo: Record.

Gonçalves, V. F. et al. 2013. Identification of Polynesian mtDNA haplogroups in remains of Botocudo Amerindians from Brazil. PNAS 110(16):6465-6469. DOI: https://doi.org/10.1073/pnas.1217905110.

Malaspinas, A. et al. 2014. Two ancient human genomes reveal Polynesian ancestry among the indigenous Botocudos of Brazil. Current Biology24(21):R1035-R1037, 2014. DOI: https://doi.org/10.1016/j. cub.2014.09.078.

Neves, W. A., e L. B. Piló. 2008. O povo de Luzia - em busca dos primeiros americanos. São Paulo: Globo.

Silva, H. P., e C. Rodrigues-Carvalho. 2006. Nossa origem - o povoamento das Américas: visões multidisciplinares. Rio de Janeiro: Vieira \& Lent.

Strauss, A. et al. 2015. Cranial morphology of the Botocudo indians, Brazil. American fournal of Physical Anthropology 157(2):202-2016. DOI: https://doi.org/10.1002/ajpa.22703. 